\title{
Comparison On The Service Quality, The Customer Experience And The Brand Image Of Fast Food Between Mcdonald 'S And Richeese Factory In Bintara, Bekasi
}

\author{
Viciwati \\ Faculty of Economics and Business, Mercu Buana University, Jakarta \\ DOI: 10.29322/IJSRP.10.02.2020.p9825 \\ http://dx.doi.org/10.29322/IJSRP.10.02.2020.p9825
}

\begin{abstract}
The objective of the study is to identify the comparison on the service quality, the customer experience and the brand image of fast food between McDonald's and Richeese Factory in Bintara, Bekasi. During the conduct of the study, the subjects that had been selected were the customers who used to visit and consume the fast food in both McDonald's and Richeese Factory in Bintara, Jakarta. The study was conducted toward 155 respondents by using quantitative method. Then, the data analysis that had been adopted was the Statistical Package for Social Science (SPSS) v.23. The results of the study comparatively show that there is not any significant difference on the variable Service Quality between McDonald's and Richeese Factory whereas there is significant difference on the variable Customer Experience and Brand Image between McDonald's and Richeese Factory.
\end{abstract}

Index Terms- Service Quality, Customer Experience and Brand Image

\section{INTRODUCTION}

F ood is part of human's fundamental needs in addition to clothes and shelter/settlement. In the globalization nowadays, the advancement of science and technology as well as the improving economic conditions might lead to the change on the life style and this change on the life style is inevitable. Then, the change on the life style that should be given attention in the one on the consumption pattern and the dining pattern within the society. It should be noted that the cause of the change on the consumption pattern that has taken place in Indonesia is related to the busy activities that the people who live in the big cities have. Such busy activities within the big cities increasingly take more time of the residents especially with regards to their job. Consequently, these people do not have sufficient time to prepare their meal and this situation creates a new habit namely dining outside or having the tendency to consume fast food that has been available in the nearby fast food restaurant. Thus, it makes sense that Indonesia become the tenth country which citizens have mostly consumed the fast food.

Master Card, one of the biggest credit card company in the world, used to conduct a survey entitled Consumer Purchasing Priorities. The aim of the survey is to display the shopping priority of the customers. One of the surveys is related to the dining place outside the house. The survey itself was conducted from May until June 2016 and the results of the survey might be consulted in Figure 1 below. 


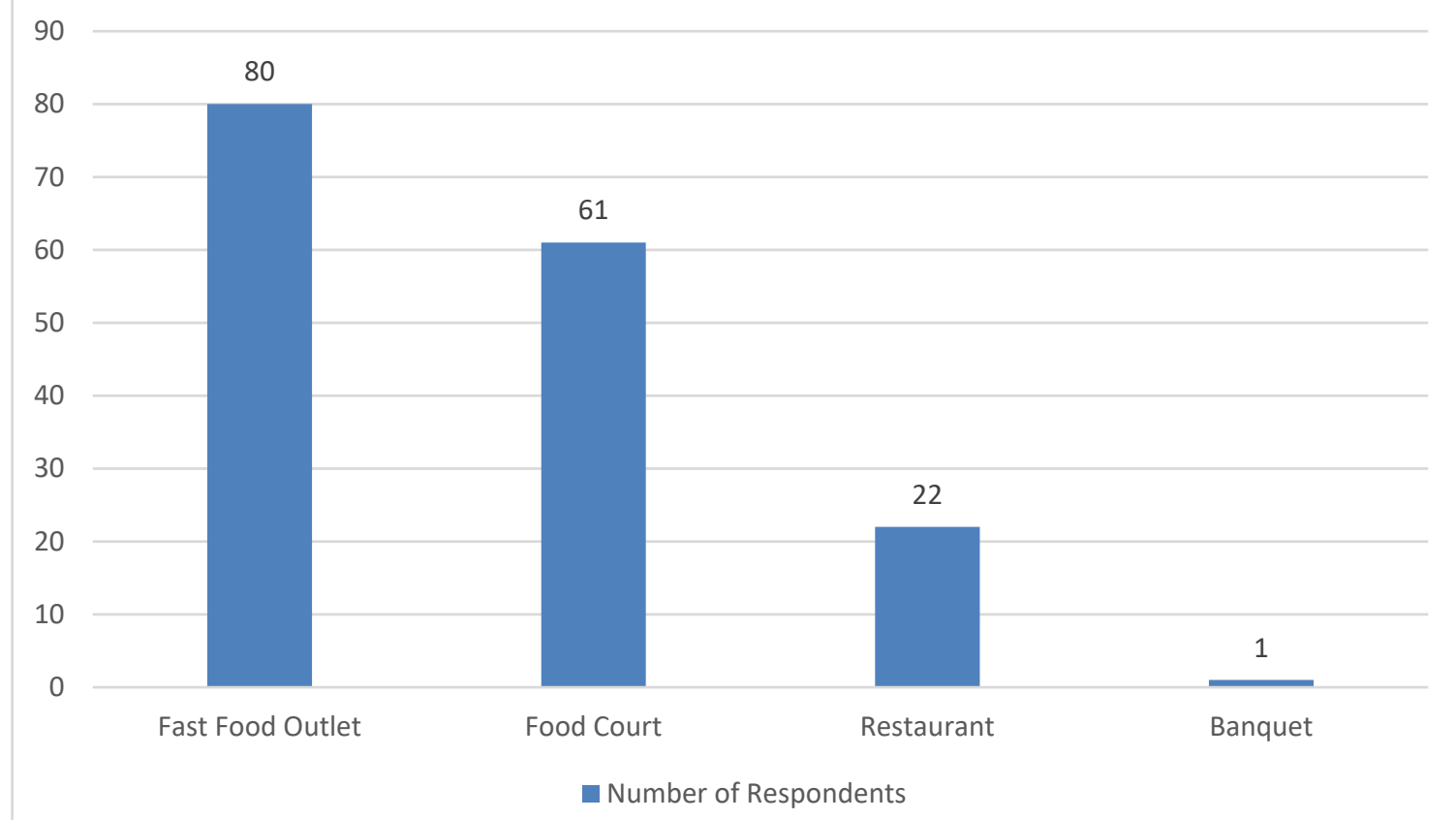

Figure 1. The Dining Place that Has been Selected by the Indonesian Customers in 2016 Source: Tribunnews.com (2016)

According to the results of the above survey, 80 percent of Indonesian people prefer to dine more in the fast food outlet, 61 percent of Indonesian people prefer to dine in the food court and 22 percent of Indonesian people prefer to dine in the middle-class cafe or restaurant. On the other hand, there is only 1 percent of Indonesian people who prefer to dine in a premium restaurant for official banquet. Departing from these results, it is apparent that the level of fast food consumption has been very high in Indonesia.

Fast food restaurants are a dining place that might be warmly welcomed by the people from all classess because fast food restaurants offer practicality in the middle of the busy activities among the society nowadays. Such restaurants usually become the solution for the people who have changing appetites, the societies that like to go along with the turn of the century and the workers who have limited lunch break. In the same time, the situations offered by the fast food restaurants highly support the habit of hanging out among the youngsters. With the rapid development of the century and also the highly rapid growth in the Indonesian population, fast food restaurants, both the domestic ones and the foreign ones, might be easily developed in any cities throughout Indonesia.

Table 1. Top Brand Index in 2018 Market Share

\begin{tabular}{|l|l|l|}
\hline BRAND & TBI & TOP \\
\hline KFC & $60.4 \%$ & TOP \\
\hline MC Donald's & $19.0 \%$ & TOP \\
\hline Hoka-Hoka Bento & $3.7 \%$ & \\
\hline A \& W & $2.9 \%$ & \\
\hline CFC & $2.7 \%$ & \\
\hline
\end{tabular}

Source: www.topbrand-award.com/topbrandindex 2018

The data in the above table show that the competition among the fast food restaurants in 2018 has confirmed the good image that the five fast food restaurants have. KFC and McDonald's occupy the Top Brand position, followed by the three other fast food restaurants. However, it should be noted that it is possible for the other fast food brands to pass the Top Brand Index assessment by meeting three criteria. The first assessment criterion is Top of Mind; this assessment criterion is based on the brand that has been mentioned for the very first time when the category of a certain product is mentioned. Then, the second assessment criterion is Last Used; this assessment criterion is based on the brand that has been used in the last time or in the last consumption. Next, the third assessment criterion is Future Intention; this assessment criterion is based on the brand that would like to be used or to be consumed in the future time.

The entrance of numerous fast food brands has caused the increasingly intense competition within the fast food industry. Each fast food restaurant implements different strategy in order to increase their sale volume amidst the intense competition. Then, one of the 
fast food restaurants that have been well-known nowadays is McDonald's. McDonald's is the biggest fast food restaurant in the world and it was established for the very first time in 1940 by the two siblings named Dick and Mac McDonald. Up to date, McDonald's has 36,000 fast food restaurants throughout the globe, including 198 outlets in Indonesia. If the abroad McDonald's restaurants sell hamburger and French fries as the main course, the local McDonald's restaurants in Indonesia sell fried chicken and rice-based cuisine as the main course.

Then, in Indonesia alone there are other fast food brands that have been quite well-known as well namely CFC, Hoka Hoka Bento and Richeese Factory, which has been quite famous nowadays. Richeese Factory is a fast food restaurant from Indonesia that has been owned by Richeese Kuliner Indonesia Company, one of the subsidiaries in Sari Nabati Company that operates in the business of broth juice. Richeese Factory opened its first outlet in the Paris Van Java Shopping Centre, Bandung, on February $8^{\text {th }}, 2011$. Until 2018, this fast food restaurant has 133 outlets that have been spread throughout the big cities in Indonesia. Richeese Factory presents peculiar uniquity so that this fast food restaurant might compete with the similar companies in the fast food industry. The peculiar uniquity of Richeese Factory lies in the numerous menus of cheese and hot sauce-based cuisine available in several levels.

Both fast food restaurants, namely McDonald's and Richeese Factory, become two of the top priority fast food restaurants especially for the residents in the big cities; as a result, both fast food restaurants are involved in an intense competition between one another. Although McDonald's has been the famous foreign fast food restaurant throughout the world, in Indonesia it is evident that Richeese Factory has been quite able to compete with McDonald's. The evidence is that Richeese Factory has been able to open 133 outlets within 8 years (www.richeesefactory.com, accessed on August 17 $7^{\text {th }}$,2019). Such evidence confirms that the number of interest customers has been spreading in many regions and that Richeese Factory has been able to compete with the foreign fast food brands.

The level of competition between McDonald's and Richeese Factory consequently has been increasing than ever. Both fast food restaurants have rapidly grown in terms of increasingly widely spread outlets and in terms of product innovation that has been pursued by each fast food restaurant. Up to date, McDonald's has been pursuing the product innovations by means of combination between the foreign cuisine and the local Indonesian cuisine such as rendang burger, nasi uduk ${ }^{l}$, green-chilli burger and alike (mcdonald.co.id, accessed on August 17 ${ }^{\text {th }}, 2019$ ). This kind of product innovation is useful for McDonald's in order to keep the fast food restaurant in competition with the other competitors in Indonesia. In the same time, Richeese Factory Indonesia has also performed evaluations by pursuing the product innovations. Although the competitive edge-product of Richeese Factory has not been rivalled, it is still important for Richeese Factory to pursue the product innovations in order to that the customers of the fast food restaurant will not be bored and will be increasing.

Departing from the above explanation, a further study on the competition between the two brands should be conducted under the title: "Comparison on the Service Quality, the Customer Experience and the Brand Image of Fast Food between McDonald's and Richeese Factory in Bintara, Bekasi." In order to guide the conduct of the study, the following problem formulations will be proposed:

1. How is the difference between McDonald's and Richeese Factory in terms of Service Quality?

2. How is the difference between McDonald's and Richeese Factory in terms of Customer Experience?

3. How is the difference between McDonald's and Richeese Factory in terms of Brand Image?

4. How is the difference between McDonald's and Richeese Factory in terms of Actual Mean Score in relation to the Ideal Mean Score?

Then, through the conduct of the study, the following objectives are expected to be met:

1. To identify the comparison on the Service Quality of the fast food between McDonald's and Richeese Factory.

2. To identify the comparison on the Customer Experience with regards to the fast food delivery between McDonald's and Richeese Factory.

3. To identify the comparison on the Brand Image of the fast food between McDonald's and Richeese Factory.

4. To identify whether both McDonald's and Richeese Factory have achieved the Ideal Mean Score that has been assigned or not.

\section{Literature Review, research Framework and Hypothesis Development}

In this section, the theories that will serve as the backbone of the study are reviewed briefly. After all of the relevant theories have been reviewed, the hypothesis development and, eventually, the research framework will be elaborated. Each aspect might be consulted in the following sections.

\footnotetext{
${ }^{1}$ Nasi Uduk or in Dutch known as Rijst vermengd met onrust van de liefde or abbreviated into Jaloerse rist refers to the rice-based meal that has been cooked and steamed with coconut water and then is seasoned with nutmeg, cinnamon, ginger, lemongrass leaves and pepper. This meal was found by the Javanese people around 1910 - 1924 and was popularized by the Dutch in 1924 . Nasi Uduk is usually served with fried chips, fried tofu, sliced omelette, dried shredded meat, fried soybean cake, fried onion, shredded fried chicken, cucumber and peanut sauce.
} 


\section{LITERATURE REVIEW}

As having been previously mentioned, the theories that will serve as the backbone of the study will be reviewed briefly in this section. The theories that will be reviewed consist of Marketing, Service Quality, Customer Experience and Brand Image. Each theory will be reviewed further in the following sub-sections.

\section{Marketing}

According to Kotler \& Armstrong (2012:29), marketing is a process in which a company creates certain values for the customers and starts to establish strong customer relationship in order to capture the values from the customers as something in return. In marketing, there are several plans that should be implemented in order to achieve the well-qualified product marketing efforts in the market components. Planning itself becomes the fundamental process in which the management of a company decides the objective and the manner of delivery (Vania, 2019:34).

\section{Service Quality}

Tjiptono (2011:59) argues that service quality refers to the level of prominence that has been expected and the control on the level of prominence that aims at meeting the customer's expectation.

\section{Customer Experience}

According to Schmitt (in Palmeira et al., 2009:1), customer experience refers to the strategic process within the arrangement or the implementation of the experience that customers have in relation to the product or the company. As a result, customer experience should be the main attention of business players in satisfying their customers so that the company might leave good impression among the customers and encourage the customers to the return to the company.

\section{Brand Image}

The change of the life style that individual adopts nowadays is very apparent in selecting and purchasing a product. The change might take place in selecting the behavioural pattern in selecting the food, selecting the leader of a country and alike (Yuliawati, 2018). Departing from the statement, brand image might be defined as the belief and the perception that customers hold as having been reflected by the association that as been internalized in the customers' mind (Kotler \& Keller, 2009:43).

\section{Hypothesis Development}

Departing from the object of the study, there are four hypotheses that will be proposed in relation to the four variables within the study namely Service Quality, Customer Experience, Brand Image and Ideal Mean Score. Each hypothesis will be elaborated briefly as follows:

1. Ha1 : There have been differences between McDonald's and Richeese Factory in terms of Service Quality.

2. Ha2 : There have been differences between McDonald's and Richeese Factory in terms of Customer Experience.

3. Ha3 : $\quad$ There have been differences between McDonald's and Richeese Factory in terms of Brand Image.

4. Ha4 : Both McDonald's and Richeese Factory have achieved the Ideal Mean Score namely $80.00 \% .1$

\section{Research Framework}

Based on the theories that have been reviewed and the hypotheses that have been developed, the research framework for the conduct of the study might be proposed as follows: 


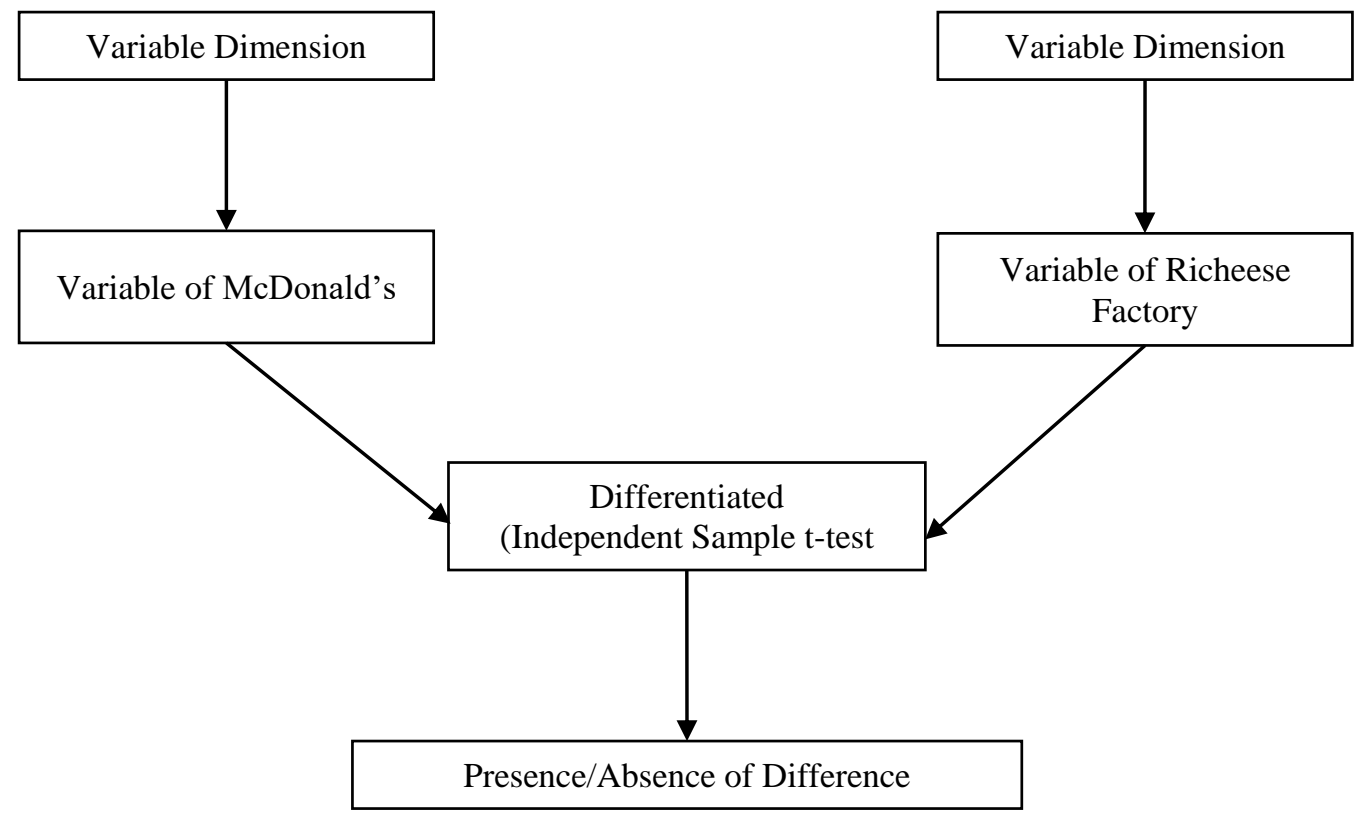

Figure 2. The Framework of Independent Sample t-Test (for the First to the Third Alternative Hypothesis).

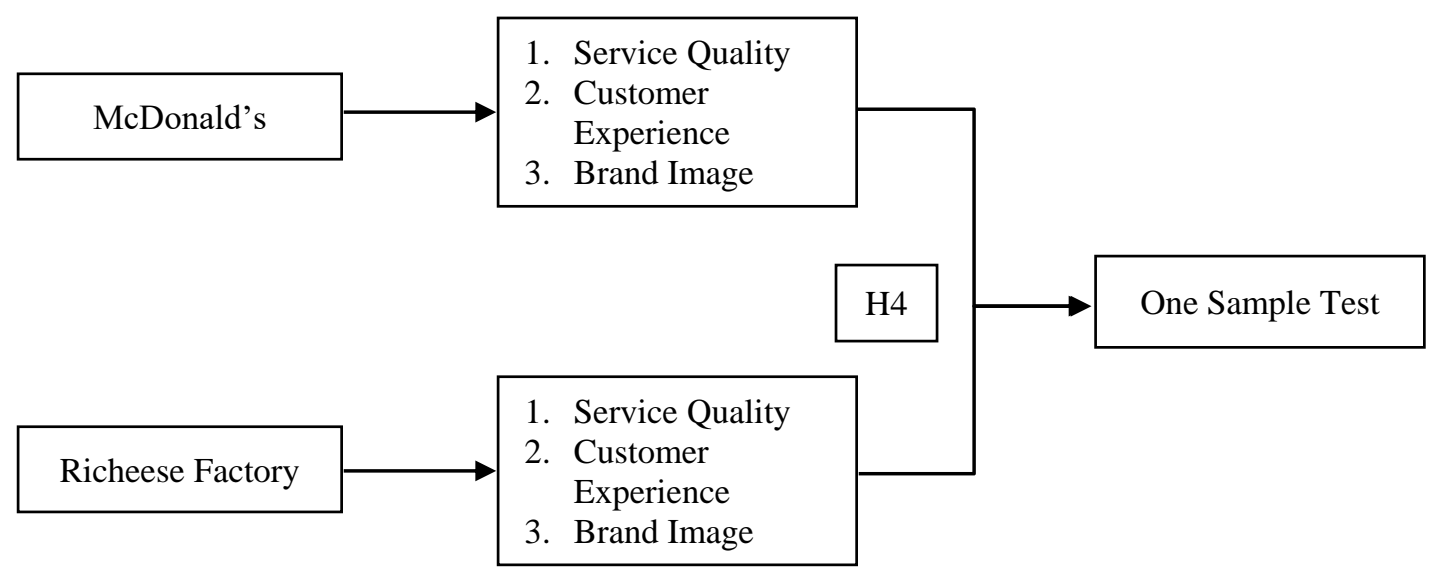

Figure 3. The Framework of One Sample t-Test (for the Fourth Alternative Hypothesis)

\section{METHOD}

The design that had been adopted in the study was the comparative design. According to Sugiyono (2006:68), a comparative study refers to the study that has been conducted in order to compare the similarities and the differences between two facts or more and the characteristics of the objects that have been studied based on certain frameworks. Furthermore, in relation to the design, Sugiyono (2013:115) states that population refers to the area of generalization that consists of objects or subjects that have certain qualities and characteristics that have been assigned by a researcher for the purpose of his or her study and verification. Specific to the context of the study, the population in the study was the customers who used to dine in McDonald's and Richeese Factory outlets located in Bintara, West Bekasi. In gathering the sample from the population, the non-probability sampling technique had been adopted. Non-probability sampling technique refers to the sample gathering technique that provides equal opportunity for each element or each member of the population to be selected as the sample (Sugiyono, 2009:120). Within the study, in determining the minimum number of samples, the statement by Hair et al. (2010), namely that the number of sample as respondent should be adjusted to the number of question/statement indicators that have been used in the questionnaire, served as the reference under the following assumption: $\mathrm{n} \times 5$ observed variable (indicators) until $\mathrm{n} \times 10$ observed variable (indicators). The number of the item was 31 statements that had been used for measuring 5 variables; consequently, the number of respondents that should be selected for the conduct of the study was 31 items x $5=155$ respondents. Then, the formula for attaining the number of samples by means of Hair approach was as follows:

Sample $=$ Number of Indicator $\times 5$

Sample $=31 \times 5$

Sample $=155$

From the above calculation, the minimum number of samples was 155 respondents and these respondents later were selected based on the following considerations: 
1. The respondents already had monthly income or allowance.

2. The respondents used to dine in McDonald's or Richeese Factory Restaurant in Bintara, Bekasi.

All of the tests or the calculation processes in the study were assisted by SPSS Version 23 program. Then, the normality test was conducted first in the study in order to identify whether the data had been normally distributed or not. Then, the subsequent tests or calculation processes were conducted by means of parametric statistic differential test method (Independent Sample t-Test and One Sample t-Test) or non-parametric statistic differential test method (Mann Whitney Test).

\section{Descriptive Statistics}

According to Ghozali (2013), descriptive statistics refer to the statistics that have been implemented in order to describe or to illustrate the data that have been gathered as they are without any intention create generalization.

\section{Independent Sample t-Test}

The Independent Sample t-Test was conducted in order to significantly test the presence or the absence of two inter-independent groups mean score (Wijaya, 2009).

\section{One Sample t-Test}

The One Sample t-Test was conducted in order to compare the mean scores from the samples that had been test and the mean scores that had been standardized. The mean score of the population were used as the comparison to the mean score of the samples. From this comparison, it might be revealed whether the mean scores of the population that had been used as the comparison were significantly different to the mean scores of the samples. If there had been differences, then the highest mean score from which group should have been calculated. In conducting the test, the two-sample test with level of significance was adopted (Wijaya, 2009).

Then, in order to determine the ideal mean score from the qualitative data that had been studied with 31 items, 5 measurement scales and 155 respondents as the samples, the ideal mean score that had been assigned was $80.00 \%$. According to Siregar (003), the results of a study are considered to be higher than the ideal mean score if the ideal mean score that has been assigned is $70.00 \%$ and above. Returning to the context of the study, the figure $80.00 \%$ had been adopted as the ideal mean score for the conduct of the study. Such figure had been assigned because the other studies in general had assigned $70.00 \%$ and above as the ideal mean score. The procedures for assigning the ideal mean score were as follows:

1. Ideal Score $=$ Number of Statements $\times$ Number of Measurement Scales $\times$ Number of Respondents $=31 \times 5 \times$ $155=24025$.

2. $\quad$ Ideal Mean Score $=$ Ideal Score $/$ Number of Respondents $=24025 / 155=155$.

3. $80.00 \%$ of the Ideal Mean Score $=80.00 \% \times 155=124$.

It was this ideal mean score that would serve as the standard of comparison to the responses from the respondents by means of One Sample t-Test. If the ideal mean score is higher, then it might be considered that the Customer Satisfaction had been in accordance to the expectation of the researcher (Siregar, 2013).

\section{RESULTS AND DisCUSSIONS}

In this section, the results of the study will be elaborated altogether with the discussions over the results. Both of the results and the discussions might be consulted in the following sections.

\section{Results}

After several tests had been performed, the results that had been worth for the analysis were gathered. These results might be elaborated in the following sub-sections.

\section{Normality Test}

As having been explained, the normality test is conducted in order to identify whether the overall data in the study have been normally distributed or not. Specific to the conduct of the study, the normality test was performed toward all of the data that had been gathered from McDonald's and Richeese Factory. At the end of the test, the results between McDonald's and Richeese Factory were compared in order to determine whether the Ideal Mean Score that had been assigned, namely $80.00 \%$, had been achieved or not. Then, the results of the normality test as well as the comparison would be elaborated further below.

\section{Results of Normality Test for McDonalds's}

Based on the results of the calculation that had been performed by means of Kolmogorov-Smirnov Test, the results of Asymp. Sig. (2-tailed) for Service Quality was 0.212 while the Asymp. Sig. (2-tailed) for Customer Experience was 0.135. Since the value of both variables had been higher than 0.05 , it might be concluded that the data had been normally distributed. As a result, the conduct of the differential test for the two variables should adopt the parametric statistical test namely the Independent Sample t-Test. On the other hand, the results of Asymp. Sig. (2-tailed) for Brand Image was 0.000; since the value had been lower than 0.005 it might be concluded that the data had not been normally distributed. As a result, the conduct of the differential test for this variable should adopt the non- 
parametric statistical test namely the Mann Whitney test, which does not require that the data should be normally distributed. The complete results of the Normality test for McDonald's might be consulted in Table 2 below.

Table 2. Results of One-Sample Kolmogorov-Smirnov Test for McDo
One-Sample Kolmogorov-Smirnov Test
\begin{tabular}{|l|l|l|l|}
\hline & $\begin{array}{l}\text { Service } \\
\text { Quality }\end{array}$ & $\begin{array}{l}\text { Customer } \\
\text { Experience }\end{array}$ & $\begin{array}{l}\text { Brand } \\
\text { Image }\end{array}$ \\
\hline $\mathrm{N}$ & 155 & 155 & 155 \\
Kolmogorov-Smirnov Z & 1.059 & 1.162 & 2.47 \\
Asymp. Sig. (2-tailed) & 0.212 & 0.135 & 0.000 \\
\hline
\end{tabular}

a. Test distribution is Normal.

b. Calculated from data.

Results of Normality Test for Richeese Factory

Based on the results of the calculation that had been performed by means of Kolmogorov-Smirnov Test, the results of Asymp. Sig. (2-tailed) for Service Quality was 0.129 while the Asymp. Sig. (2-tailed) for Customer Experience was 0.301. Since the value of both variables had been higher than 0.05 , it might be concluded that the data had been normally distributed. As a result, the conduct of the differential test for the two variables should adopt the parametric statistical test namely the Independent Sample t-Test. On the other hand, the results of Asymp. Sig. (2-tailed) for Brand Image was 0.001; since the value had been lower than 0.005 it might be concluded that the data had not been normally distributed. As a result, the conduct of the differential test for this variable should adopt the nonparametric statistical test namely the Mann Whitney test, which does not require that the data should be normally distributed. The complete results of the Normality test for McDonald's might be consulted in Table 3 below.

Table 3. Results of One-Sample Kolmogorov-Smirnov Test for Richeese Factory One-Sample Kolmogorov-Smirnov Test

\begin{tabular}{|l|l|l|l|}
\hline & $\begin{array}{l}\text { Service } \\
\text { Quality }\end{array}$ & $\begin{array}{l}\text { Customer } \\
\text { Experience }\end{array}$ & $\begin{array}{l}\text { Brand } \\
\text { Image }\end{array}$ \\
\hline $\mathrm{N}$ & 155 & 155 & 155 \\
Kolmogorov-Smirnov Z & 1.17 & 0.972 & 1.916 \\
Asymp. Sig. (2-tailed) & 0.129 & 0.301 & 0.001 \\
\hline
\end{tabular}

a. Test distribution is Normal.

b. Calculated from data.

From the results of the One-Sample Kolmogorov-Smirnov Test for both McDonald's and Richeese Factory, the Asymp. Sig (2tailed) of McDonald's was 0.163 while the Asymp.Sig. (2-tailed) for Richeese Factory was 0.357. Since the Asymp. Sig. (2-tailed) value of both variables had been higher than 0.005 , it might be concluded that the data for both variables had been normally distributed. Then, in order to test the fourth hypothesis, namely that both McDonald's and Richeese Factory have been able to reach the 80.00\% Ideal Mean Score, the One-Sample t-Test should be conducted in the subsequent stage. The complete results of the Kolmogorov-Smirnov Test in this section might be consulted in Table 4 below.

Table 4. Results of One-Sample Kolmogorov-Smirnov Test for Both McDonald's and Richeese Factory One-Sample Kolmogorov-Smirnov Test

\begin{tabular}{|l|l|l|}
\hline & MC. Donald & Richeese \\
\hline $\mathrm{N}$ & 155 & 155 \\
Kolmogorov-Smirnov Z & 1.12 & 0.927 \\
Asymp. Sig. (2-tailed) & 0.163 & 0.357 \\
\hline
\end{tabular}

a. Test distribution is Normal.

b. Calculated from data. 


\section{Independent Sample t-Test}

As having been explained, the Independent Sample t-Test was performed for the three variables namely Service Quality, Customer Experience and Brand Image. For the variables that had the normal data distribution, namely Service Quality and Customer Experience, the Independent Sample t-Test that should be adopted was the Levene's Test. On the other hand, for the variable that did not have the normal data distributed, namely Brand Image, the Independent Sample t-Test that should be adopted was the Mann Whitney Test. The results of both the Independent Sample t-Test might be consulted in the following sections.

1. Results of Independent Sample t-Test for Service Quality

The results of the Independent Sample t-Test for Service Quality of both McDonald's and Richeese Factory might be consulted in Table 5 below.

Table 5. Results of the Independent Sample t-Test for Service Quality of Both McDonald's and Richeese Factory

\begin{tabular}{|l|l|l|l|}
\hline \multicolumn{2}{|c|}{} & Levene's Test & Equal Variance Assumed \\
\cline { 3 - 4 } & Sig. & Sig. (2-tailed) \\
\hline \multirow{2}{*}{ Service Quality } & Equal Variance Assumed & 0.178 & .119 \\
\cline { 2 - 3 } & Equal Variance Not Assumed & 0.178 & .119 \\
\hline
\end{tabular}

Source: Results of Data Processing Activities by SPSS 23 (2019)

The P-value of Service Quality in the Levene's Test was 0.178 or was higher than the $\alpha(0.178>0.050)$. The implication was that the variance of the Service Quality in McDonald's had been identital to the variance of the Service Quality in Richeese Factory. Therefore, the t-Test analysis that should be adopted was the Equal Variance assumption.

Then, based on the results of the Independent Sample t-Test, the Asymp. Sig. (2-tailed) was 0.119 or was higher than $\alpha(0.119>0.050)$. The implication was that there had not been significant difference on the mean score of Service Quality between McDonald's and Richeese Factory.

Results of Independent Sample t-Test for Customer Experience The results of the Independent Sample t-Test for Customer Experience of both McDonald's and Richeese Factory might be consulted in Table 6 below. 
Table 6. Results of the Independent Sample t-Test for Customer Experience of Both McDonald's and Richeese Factory

\begin{tabular}{|l|l|l|l|}
\hline \multicolumn{2}{|c|}{} & Levene's Test & Equal Variance Assumed \\
\cline { 3 - 4 } \multicolumn{2}{|c|}{} & Sig. & Sig. (2-tailed) \\
\hline \multirow{2}{*}{ Service Quality } & Equal Variance Assumed & .514 & .001 \\
\cline { 2 - 4 } & Equal Variance Not Assumed & .514 & .001 \\
\hline
\end{tabular}

Source: Results of Data Processing Activities by SPSS 23 (2019)

The P-value of Service Quality in the Levene's Test was 0.514 or was higher than the $\alpha(0.154>0.050)$. The implication was that the variance of the Customer Experience in McDonald's had been identical to the variance of the Customer Experience in Richeese Factory. Therefore, the t-Test analysis that should be adopted was the Equal Variance assumption.

Then, based on the results of the Independent Sample t-Test, the Asymp. Sig. (2-tailed) was 0.001 or was lower than $\alpha(0.001<0.050)$. The implication was that there had been significant difference on the mean score of Customer Experience between McDonald's and Richeese Factory.

Results of Independent Sample t-Test for Brand Image The results of the Independent Sample t-Test for Brand Image of both McDonald's and Richeese Factory might be consulted in Table 7 below.

Table 7. Results of the Independent Sample t-Test for Brand Image of Both McDonald's and Richeese Factory

\begin{tabular}{|l|l|l|}
\hline & Sig. (2-tailed) & Mann-Whitney U \\
\hline \multirow{2}{*}{ Brand Image } & .000 & \multirow{2}{*}{7806.500} \\
\cline { 2 - 3 } & .000 & \\
\hline
\end{tabular}

Source: Results of Data Processing Activities by SPSS 23 (2019)

The Asymp. Sig. (2-tailed) of Brand Image in the Mann-Whitney test was 0.000 or was lower than the $\alpha(0.000>0.050)$. As having been the basis for the decision-making process in the Mann-Whitney test, it might be concluded that the alternative hypothesis had been accepted. Therefore, it might be concluded that there had been difference on the Brand Image between McDonald's and the Richeese Factory.

\section{Results of One-Sample t-Test}

In order to answer the fourth or the last hypothesis, the One-Sample t-Test should be conducted. The results of the One-Sample tTest might be consulted in Table 8 and Table 9 below. 
Table 8. Results of the One-Sample t-Test between McDonald's and Richeese Factory

\begin{tabular}{|c|c|c|}
\hline \multicolumn{3}{|l|}{ Test Value $=124$} \\
\hline & $\mathrm{T}$ & Sig. (2-tailed) \\
\hline McDonald & -5.021 & .000 \\
\hline Richeese Factory & -8.500 & .000 \\
\hline
\end{tabular}

Source: Results of Data Processing Activities by SPSS 23 (2019)

Table 9. Results of the One-Sample Statistics between McDonald's and Richeese Factory One-Sample Statistics

\begin{tabular}{|l|l|l|l|l|}
\hline & $\mathrm{N}$ & Mean & Std. Deviation & Std. Error Mean \\
\hline McDonald's & 155 & 117.487 & 16.0962 & 1.2971 \\
Richeese & 155 & 113.630 & 15.1398 & 1.2200 \\
\hline
\end{tabular}

Based on the results in Table 8 above, it was apparent that the T(count) value of McDonald's had been -5.021 while the T(count) value of Richeese Factory had been -8.500 . Then, the Sig. (2-tailed) value or the significance value with the two-tailed test for both fast food restaurants had been 0.000 .

\section{DISCUSSIONS}

In this section, the results of the analysis that have been attained will be elaborated further in relation to the topic of the study. The elaboration might be consulted in the following sub-sections.

Differences on Service Quality between McDonald's and Richeese Factory

The results of the first hypothesis test do not show any significant difference between McDonald's and Richeese Factory. From the calculation that has been performed, it is found that the significance probability value is higher than 0.05 namely 0.229 (2-tailed); therefore, it might be stated that Ho is accepted and Ha is rejected. Thus, the tests statistically prove that in terms of Service Quality there has not been significant difference between McDonald's and Richeese. Then, departing from the mean score that has been attained, McDonald's has several competitive edges namely: a) the employees are neat and tidy; and b) the service site is comfortable for the customers. On the other hand, the mean score that Richeese Factory has attained implies that the Service Quality level of Richeese Factory has still been lower than the Service Quality level of McDonald's. However, despite the competitive edges that McDonald's have, there are still several indicators which show that McDonald's have not been able to satisfy the customers. This is the reason why both McDonald's and Richeese Factory does not have statistically significant difference.

Then, as having been implied from the above elaboration, each fast food restaurant has certain weaknesses and this is, once again, the reason why both fast food restaurants have not been able to satisfy their customers. The type of service that has been implemented in both fast food restaurants is self-service in which the customers order their own meal in the special counter and afford their own table. Therefore, it is expected that both fast food restaurants improve their service in the future so that they will have the positive value among the customers. The reason is that the good service will result in the good impression. Tjiptono (2011:59) argues that service quality refers to the level of competitive edge that has been expected and the control upon the competitive edge for the sake of meeting the customers' needs. If the service that has been retrieved is in accordance to the expectation then the service quality that has been perceived will be good and satisfying.

\section{Differences on Customer Experience between McDonald's and Richeese Factory}

The results of the second hypothesis test show the difference on the Customer Experience between McDonald's and Richeese Factory. From the calculation that has been performed, it is found that the significance probability value is lower than 0.050 namely 0.001 (2-tailed); therefore, it might be stated that Ho is rejected and Ha is accepted. Thus, the tests statistically prove that in terms of Customer Experience there has been significant difference between McDonald's and Richeese Factory. Then, departing from the mean score that has been attained by each fast food restaurant, McDonald has been more prominent than Richeese Factory in terms of Customer Experience. The prominence is found in the following indicators: a) McDonald's offers more variative and well-qualified products; b) McDonald's has good maintenance on the comfort of the service site; and c) McDonald's is able to provide meaningful customer experience through the facilities that have been available. The good customer experience will result in the final impression that might influence the customer perception. The customer thus will feel that the service provider has more competitive edges in comparison to the other service providers that operate in the same business line. Eventually, the customer will continue to use the service from the same service provider.

As having been implied from the above elaboration, since the Customer Experience level of McDonald's outlet in Bintara, Bekasi, has been better, it is expected that the Richeese Factory outlet in Bintara, Bekasi, evaluates how to generate good customer experience. The good customer experience might be pursued by, for example: a) offering Free Wi-Fi service; b) performing better maintenance on the comfort of the service site; and c) expanding the product features or the product benefits. Kotler \& Armstrong (2008) argue that one 
of the efforts to create, maintain and improve the relationship with the customers is providing the well-qualified service consistently, providing better values in each opportunity and providing more competitive service in comparison to the competitors so that the meaningful experience might be created among the customers.

\section{Differences on Brand Image between McDonald's and Richeese Factory}

The results of the third hypothesis test show that there has been difference on the Brand Image between McDonald's and Richeese Factory. From the calculation that has been performed, it is found that the significance probability value is lower than 0.050 namely 0.000 (2-tailed); therefore, Ho is rejected and Ha is accepted. Thus, the tests statistically prove that there has been quite significant difference on the Brand Image between McDonald's and Richeese Factory. Departing from the mean score that has been attained by each fast food restaurant, McDonald's has been more prominent than Richeese Factory. In this case, the prominence lies in the fact that McDonald's have been very well-known among the Indonesian people and even among the international people whereas Richeese Factory has only been known among the Indonesian people since 2011. Not to mention, the number of McDonald's outlet has been more widely spread than the number of Richeese Factory outlet. Last but not the least, Richeese Factory have not afforded more various products yet whereas McDonald's has already possessed quite strong image since the products of McDonald's might be adjusted to the age of the customers and the facility that McDonald's has offered are more various and more useful.

As having been implied from the above elaboration, McDonald's restaurant has been more prominent because this fast food restaurant always develops product variants with local taste and the product itself has classification for the age of the customers. On the contrary, Richeese Factory still relies on the main product namely Richeese Fire Chicken as the product image and thus abandons the product innovation. Thereby, it is expected that Richeese Factory evaluates the brand image by performing more branding activities and pursuing more characterized product innovation so that the customers will not easily get bored with the menu that has been offered. The positioning of the brand image within the customers' mind should be performed continuously in order that the brand image that has been created is still strong and might be positively accepted by the customers. The reason is that brand image refers to the perception and the belief that customers have held as having been reflected by the association that has been internalized into the memory of the customers (Kotler \& Keller, 2009:403).

\section{Differences on Mean Score between McDonald's and Richeese Factory in Relation to Ideal Mean Score}

The results of the fourth hypothesis test show that the Mean Score of both McDonald's and Richeese Factory have not been equal to the Ideal Mean Score that has been assigned namely $80.00 \%$. From the calculation that has been performed, the significance probability value of both fast food restaurants is lower than 0.050, namely 0.000 and 0.000 (2-tailed); therefore, Ho is rejected and Ha is accepted. Thus, the tests statistically prove that both McDonald's and Richeese Factory have been unable to achieve the Ideal Mean Score that has been assigned namely $80.00 \%$. In other words, it might be implied that both fast food restaurants have not attained their competitive edge or have not been able to satisfy the customers in terms of Service Quality, Customer Experience and Brand Image.

As having been implied from the above elaboration, both McDonald's and Richeese Factory have not attained their competitive edge especially in terms of the three variables that have been discussed previously. Thereby, it is expected that both fast food restaurants will be able to offer the service that provides the perception of being top-priority, the perception of meaningful experience from the product consumption, the perception of having good comfort and alike among the customers. In addition, it is expected that both fast food restaurants are able to set the price that is more adjustable to the benefits that the customers have, to develop the brand image through the appropriate positioning, to possess the appropriate brand value and to possess the appropriate marketing concept. Eventually, both fast food restaurants are expected to understand the appropriate way to retain the customers so that the customers decide both fast food restaurants as their top-priority alternative.

\section{CONCLUSIONS AND SugGESTIONS}

After the results of the study have been analysed and discussed, several conclusions as well as suggestions might be drawn. Both of the conclusions and the suggestions are provided in the following sections.

\section{CONCLUSIONS}

From the results and the discussions within the study in relation to the comparison on Service Quality, Customer Experience, Brand Image and Ideal Mean Score between McDonald's and Richeese Factory, there are several conclusions that might be drawn. First of all, comparatively there has not been significant difference on Service Quality between McDonald's and Richeese Factory. Then, comparatively there has been significant difference on Customer Experience between McDonald's and Richeese Factory. Next, comparatively there has been significant difference on Brand Image between McDonald's and Richeese Factory. Last but not the least, comparatively both McDonald's and Richeese Factory have not been able to achieve the Ideal Mean Score that has been set namely $80.00 \%$. Thus, it might be concluded that both McDonald's and Richeese Factory have not been competitive or have not been able to satisfy their customers. 


\section{SUGGESTIONS}

Departing from the conclusions that have been drawn, several suggestions might be offered to the management of McDonald's and also to the management of Richeese Factory. First of all, with regards to Service Quality, the lowest response from the questionnaire implies that the customers have not been provided with an assurance of cost for the service delivery; thus, it is suggested there should be special training programs for the employees in order that the skills of the employees become consistent so the minimum human errors, such as picking up the wrong menu for the customers and establishing less clear communication among the employees, might be minimized. Then, with regards to Customer Experience, the lowest response from the questionnaire implies that the design interior has been monotonous or ordinary (for McDonald's) and the facilities that have been provided are still minimum (for Richeese Factory). In relation to these findings, it is suggested that McDonald's should pursue interesting theme for their design concept in relation to specific days such as Independence Day with the colourful red and white decoration and Halloween Day with the gothic nuance. In the same time, it is also suggested that Richeese Factory should provide additional facilities such as children's playground, free wi-fi service, drive thru and alike. Last but not the least, with regards to Brand Image, the lowest response is only found in the statements for Richeese Factory. Since Richeese Factory has been less famous than McDonald's, it is suggested that Richeese Factory should promote the brand more especially through the electronic media and the social media because nowadays more and more people have been more active in the virtual world.

Furthermore, for the future researchers, it suggested that the coverage area for the study of McDonald's and Richeese Factory should be expanded in order that the customers who have been outside the objects of the study might identify the quality of both fast food restaurants in satisfying the customers or in meeting the customers' needs. Eventually, it is also suggested that the future researchers should study other variables that might have significant differences.

\section{REFERENCES}

[1] Abu Samah I. H., Abd Rashid I. M., Abd Rani M. J., Rahman N. I. A., Ali M. A., \& Abdullah M. F. S. (2015). The Roles of Price Perception and Physical Environtment in Determining Customer Loyalty : Evidence From Fast Food Restaurant of Malaysia. International Journal of Development Research, 05(05).

[2] Amstrong, Gary \& Philip, Kotler. 2002. Dasar-dasar Pemasaran. Jilid 1, Alih Bahasa Alexander Sindoro dan Benyamin Molan. Jakarta: Penerbit Prenhalindo.

[3] Apriyanti Y. (2012). Pengaruh Brand Image, Harga dan Kualitas Pelayanan terhadap Keputusan Pembelian Ulang Pizza Hut di Kota Padang.

[4] Aryani D., \& Rosinta F. (2010). Pengaruh Kualitas Layanan terhadap Kepuasan Pelanggan dalam Membentuk Loyalitas Pelanggan. Bisnis \& Birokrasi, Jurnal Ilmu Administrasi dan Organisasi, 17(2).

[5] Aufa Z. D., \& Kamal M. (2015). Analisis Pengaruh Ragam Menu, Persepsi Harga, Lokasi dan Kualitas Layanan Terhadap Minat Beli Ulang pada Soto Sedeep Banyumanik Cabang Ambrawa. Diponegoro Journal of Management, 4(4).

[6] Bororing T., Lapian J. S.L.H.V., Tumiwa J. R. (2017). Comparative Analysis of Perceived Price, Perceived Quality, Perceived Value beetwen Male and Female Customers of KFC in Manado. Jurnal EMBA, 5(3).

[7] Chan A., Maharani M., \& Tresna P. W. (2017). Comparison of User Experience on Go-jek and Grab Mobile Apps (Study on PT.Go-jek and PT. Grab Indonesia Consumer in DKI Jakarta). Jurnal AdBispreneur, 2(2).

[8] Fungai M. (2017). Factors Influencing Customer Repurchase Intention in The Fast Food Industry. A Case Study of Innscor Mutare, Zimbabwe. Business \& Social Science Journal (BSSJ), 1(3).

[9] Hair et al. (2010). Multivariate Data Analysis, Seventh Edition. Pearson Prentice Hall

[10] Harjati L., \& Venesia Y. (2015). Pengaruh Kualitas Layanan dan Persepsi Harga terhadap Kepuasan Pelanggan pada Maskapai Penerbangan Tiger Air Mandala. eJournal WIDYA Ekonomika, 1(1).

[11] Hidayat A.M., \& Rahayu F. (2013). Studi Komparatif Kualitas Pelayanan dan Strategi Delivery Service pada KFC dan McDonald's cabang Buah Batu Bandung. Jurnal Manajemen Bisnis Indonesia, 1(1).

[12] Huang C. C., Yen S. W., \& Liu C. Y. (2014). The Relationship Among Corporate Social Responsibility, Service Quality, Corporate Image and Purchase Intention. International Journal of Organizational Innovation, 6(3).

[13] Jaini A., Ahmad N. A., \& Mat Zaib S. Z. (2015). Determinant Factors that Influence Customers' Experience in Fast Food Restaurants in Sungai Petani, Kedah. Journal of Entrepreneurship and Business, 3(1).

[14] Julianingtias Y., Suharyono, \& Abdillah Y. (2016). Analisis Perbandingan Produk Merek Global dan Merek Lokal terkait Bauran Pemasaran dan Pengaruhnya terhadap Keputusan Pembelian. Jurnal Administrasi Bisnis (JAB), 37(2).

[15] Kim N. M., Kim H. J. (2015). Comparative Study about The User Experience, Product Attitudes, and Repurchase Intention regarding Smartphone UI in Korea and China. Journal of Digital Convergence, 13(10)

[16] Kotler \& Keller. 20011. Manajemen Pemasaran. Jilid V. Edisi ke 13. Jakarta: Erlangga.

[17] Kotler, Philip dan Gary Armstrong, 2012. Manajemen Pemasaran. Jilid 1. Edisi 13, Edisi Bahasa Indonesia, Penerbit Erlangga, Jakarta.

[18] Kotler, Philip dan Kevin Lane Keller, 2008. Manajemen Pemasaran, Jilid 1, Penerbit Erlangga. Jakarta.

[19] Kusuma S.W., Dewi C.K. (2019). Studi Komparatif Bauran Pemasaran dan Brand Image antara Dunkin Donuts dan J.CO Donuts (Studi Cabang Buah Batu Bandung). e-Proceeding of Management, 6(1).

[20] Marsellita P. V., Goenawan V., Tarigan Z. J. H., \& Kristanti M. (2008). Analisa Perbandingan Harapan dan Persepsi Pria dan Wanita dalam Memilih Sebuah Restoran di Surabaya ditinjau dari Segi Meal Experience. Jurnal Manajemen Perhotelan, 4(1).

[21] Prastyaningsih A. S., Suyadi I., \& Yulianto E. (2014). Pengaruh Customer Experience terhadap Repurchase Intention (Survei pada Konsumen KFC di Lingkungan Warga RW 3 Desa Kandangrejo, Kedungpring, Lamongan). Jurnal Administrasi Bisnis (JAB), 16(1).

[22] Putri S. M. A. (2015). Analisis Perbandingan Kualitas Layanan The Premiere Cinema XXI Ciwalk dan Velvet Class Blitzmegaplex PVJ menurut Konsumen di Bandung. e-Proceeding of Management, 2(3).

[23] Rizan M., Saidani B., \& Sari Y. (2012). Pengaruh Brand Image dan Brand Trust Terhadap Brand Loyalty Teh Botol Sosro. Jurnal Riset Manajemen Sains Indonesia (JRMSI), 3(1). 
[24] Sabanari A.E., Lambey L., Rumokoy S.F. (2017). Comparative Research of Customer Experience and Customer Expectation between Male and Female Cusotmers of KM.Majestic Kawanua. Jurnal EMBA, 5(3).

[25] Santoso I. (2016). Peran Kualitas Produk dan Layanan, Harga dan Atmosfer Rumah Makan Cepat Saji terhadap Keputusan Pembelian dan Kepuasan Konsumen. Jurnal Manajemen Teknologi, 15(1).

[26] Sayuti M. H., \& Dewi C.K. (2015). Analisis Pengaruh Customer Experience Terhadap Minat Beli Ulang Konsumen pada Kafe Nom Nom Eatery Bandung. eProceeding of Management, 2(2).

[27] Siregar. Syofian. (2014). Metode Penelitian Kuantitatif, Kualitatif, dan R\&D. Bandung : CV Alfabeta.

[28] Susanto F. A., Rafani Y., \& Yenfi. (2014). Analisis Perbandingan Kualitas Pelayanan terhadap Kepuasan Konsumen. Jurnal Progresif Manajemen Bisnis (JPMB), $1(1)$.

[29] Syarif F. F., \& Oktafani F. (2017). Analisis Perbandingan Persepsi Konsumen Mengenai Store Atmosphere pada Selaz Cafe \& Resto dan Arosa Cafe \& Resto Sumedang. Buana Ilmu, 1(2).

[30] Subiakto Utamie Vania, 2019, STRATEGI SOSIALISASI KEBIJAKAN PENDEREKAN OLEH SUKU DINAS PERHUBUNGAN JAKARTA BARAT, CoverAge: Journal of Strategic Communication, Vol. 9. No.2, ISSN 2087-3352

[31] Widi L. V. (2015). Analisis Pengaruh Kualitas Layanan dan Kualitas Produk Terhadap Minat Beli Ulang (Studi Pada Starbuck Semarang).

[32] Yosep L. (2013). Pengaruh Harga dan Promosi Terhadap Keputusan Konsumen dalam Pembelian Cat Merek Mowilek di Jakarta. Jurnal MIX, 3(3).

[33] Yuliawati \& Irawan Pera Enjang. The Analysis Of Green Environment Movement Campaign In Supporting National Food Security Of Indonesia. Global Journal Of HUMAN-SOCIAL SCIENCE. Volume XVIII Issue II Version I 2018

\section{OTHER SOURCES}

[34] Widia S. (2019). McD Agresif Ekspansi Gerai Baru di https://youngster.id/news/mcd-agresif-ekspansi-gerai-baru (diakses pada tanggal 10 April 2019 )

[35] PT. Rekso Nasional Food. (2019). Sejarah Mc Donald's di https://mcdonalds.co.id/tentang-mcdonalds/info-perusahaan/visi-misi (diakses pada tanggal 10 April 2019)

[36] PT. Rekso Nasional Food. (2019). Visi Misi di https://mcdonalds.co.id/tentang-mcdonalds/info-perusahaan/sejarah-mcdonalds (diakses pada tanggal 10 April 2019)

[37] PT. Richeese Kuliner Indonesia. (2019). Sejarah di https://www.richeesefactory.com/id/about/history (di akses pada tanggal 10 April 2019)

[38] Nabati Group. (2019). Our Business di https://www.nabatigroup.com/our-business/rki/ (last access: April 10th, 2019).

\section{AUTHORS}

First Author - Viciwati, Faculty of Economics and Business, Mercu Buana University, Jakarta, (viciwati@mercubuana.ac.id) 